Article

\title{
Enantioselective Transesterification of Allyl Alcohols with (E)-4-Arylbut-3-en-2-ol Motif by Immobilized Lecitase $^{\mathrm{TM}}$ Ultra
}

\author{
Aleksandra Leśniarek ${ }^{1, *}$, Anna Chojnacka ${ }^{1}$, Radosław Drozd ${ }^{2} \mathbb{D}$, Magdalena Szymańska ${ }^{2}$ (D) \\ and Witold Gładkowski ${ }^{1, * \mathbb{D}}$ \\ 1 Department of Chemistry, Wroclaw University of Environmental and Life Sciences, Norwida 25, \\ 50-375 Wroclaw, Poland; anna.chojnacka@upwr.edu.pl \\ 2 Department of Microbiology and Biotechnology, Faculty of Biotechnology and Animal Husbandry, \\ West Pomeranian University of Technology, Szczecin, 45 Piastów Avenue, 71-311 Szczecin, Poland; \\ rdrozd@zut.edu.pl (R.D.); magdalena.szymanska@zut.edu.pl (M.S.) \\ * Correspondence: aleksandra.jurabio@gmail.com (A.L.); witold.gladkowski@upwr.edu.pl (W.G.); \\ Tel.: +48-713205154 (W.G.)
}

Received: 12 June 2020; Accepted: 15 July 2020; Published: 17 July 2020

\begin{abstract}
Lecitase ${ }^{\mathrm{TM}}$ Ultra was immobilized on four different supports and tested for the first time as the biocatalyst in the kinetic resolution of racemic allyl alcohols with the (E)-4-arylbut-3-en-2-ol system in the process of transesterification. The most effective biocatalyst turned out to be the enzyme immobilized on agarose activated with cyanogen bromide (LU-CNBr). The best results $\left(\mathrm{E}>200, e e_{\mathrm{s}}\right.$ and $\left.e e_{\mathrm{p}}=95-99 \%\right)$ were obtained for $(E)-4$-phenylbut-3-en-2-ol and its analog with a 2,5-dimethylphenyl ring whereas the lowest ee of kinetic resolution products (90\%) was achieved for the substrate with a 4-methoxyphenyl substituent. For all substrates, $(R)$-enantiomers were esterified faster than their $(S)$-antipodes. The results showed that $\mathrm{LU}-\mathrm{CNBr}$ is a versatile biocatalyst, showing high activity and enantioselectivity in a wide range of organic solvents in the presence of commonly used acyl donors. High operational stability of LU-CNBr allows it to be reused in three subsequent reaction cycles without negative effects on the efficiency and enantioselectivity of transesterification. This biocatalyst can become attractive to the commercial lipases in the process of the kinetic resolution of allyl alcohols.
\end{abstract}

Keywords: Lecitase Ultra; enzyme immobilization; optically active alcohols; enantioselective transesterification; kinetic resolution; operational stability

\section{Introduction}

Using enzymes as the biocatalysts of chemical reactions is a subject of interest for many researchers worldwide due to their wide spectrum of activity and high stereo- and regioselectivity [1-3]. New environmental requirements concerning "green chemistry" have also made the enzymes attractive industrial catalysts, as they can be used in mild reaction conditions (aqueous phase, normal pressure, room temperature) [4-6]. However, different enzyme features, including activity, selectivity, and operational stability, can be improved using different metagenomics tools [7-9]. One of them is a production of chimeric enzymes by mixing the genes of two different proteins to join their desired properties [10-12].

An example of such an approach is a preparation named Lecitase ${ }^{\mathrm{TM}}$ Ultra (LU), produced initially by Novo Nordisk A/S by the fusion of genes of the lipase from Thermomyces lanuginosus and phospholipase $A_{1}$ from Fusarium oxysporum [13]. This enzyme was designed for the degumming of plant oils, which is the first step in the rafination of vegetable oils. In this process, both hydratable 
and nonhydratable phospholipids (NHPs) present in the oil are hydrolyzed by LU to the more soluble lysophospholipids facilitating their washout, yielding the oil with a low amount of phosphorous [14]. As a chimera, LU combined the stability of lipase with the activity of phospholipase $\mathrm{A}_{1}$, that is an acylhydrolase catalyzing the hydrolysis of acyl chains of phospholipids in sn-1 position [15-17]. Shortly, the range of applications of this enzyme was expanded to the typical lipase-catalyzed reactions. One of the most explored was the production of diacylglycerols by different strategies, including partial hydrolysis of vegetable oils [18-21], glycerolysis of vegetable oils [22], or esterification of glycerol with fatty acids $[23,24]$. LU was also successfully applied to the modifications of acyl chains in phospholipids by acidolysis or transesterification with fatty acids or their esters, respectively [25-28]. In the area of asymmetric synthesis, it was used for the enantioselective hydrolysis of some racemic mixtures, including mandelic acid derivatives [29], glycidate esters [30,31], $\alpha$-aminoacids [32], and 4-arylbut-3-en-2-yl esters [33,34].

Due to the beneficial effects of immobilization on different properties of the enzyme, including stability, purity, activity, and selectivity, as well as simpler separation from the reaction mixtures posing the possibility of recovery and reuse [35-38], for many purposes, LU has been immobilized on different supports using different techniques [39-42].

Immobilization of enzymes by adsorption is one of the oldest and also the most frequently used methods due to the relatively low costs and simple procedure. LU adsorbed physically on cellulose triacetate was used for the production of fatty acid methyl esters from soybean oil by transesterification [43]. Adsorption of LU on different ionic and macropourous resins found applications in lipid chemistry, including acidolysis of phospholipids [28,44,45], glycerolysis of soybean oil [46], esterification of glycerol with oleic acid [47], hydrolysis of phosphatidylcholine to lysophosphatidylcholine [48], and esterification of isopropylidene glycerol in the production of monoacylglycerols [49].

Enzyme trapping involves the binding of a biocatalyst inside a selectively permeable membrane, and the process is based on relatively weak physical interactions between the matrix and the enzyme, which prevents interference with the three-dimensional structure of the protein. Examples of using this technique for LU are the immobilization of this enzyme in calcium alginate-based supports for the degumming of vegetable oils [50] or entrapping LU in a gelatin matrix for kinetic resolution of 2-hydroxy acid esters and glycidate esters [30,32] and the degumming of rice bran oil [51] as well as the encapsulation of LU in AOT/isooctane reverse micelles for esterification of oleic acid with ethanol [52].

Immobilization of the enzyme by covalent bonds requires a support that must be previously activated to introduce the appropriate functional moieties, which can react with complementary functional groups of proteins. One of the most exploited carriers from this group is agarose activated with cyanogen bromide. LU immobilized on this support (LU-CNBr) was used for the hydrolytic resolution of racemic esters of mandelic acid [29], asymmetric hydrolysis of prochiral dimethyl 3-phenylglutarate [53], and hydrolytic deprotection of carbohydrate derivatives [54]. LU immobilized on acrylic polymer Immobead-350, activated with various functional groups, was applied to the hydrolysis of the $R$ - and $S$-methyl mandelate and to the transesterification of benzyl alcohol with vinyl acetate [55]. An interesting example of enzyme immobilization is covalent binding of LU with functionalized magnetic bacterial cellulose [56].

Enantiomers of alcohols with the (E)-4-arylbut-3-en-2-ol motif are important chiral precursors in the synthesis of some chiral drugs like Baclofen [57] or Verapamil [58] as well as optically active lactones with antiproliferative activity toward cancer lines $[59,60]$. These alcohols can be obtained by the enzymatic resolution of racemic mixtures. In our previous papers, we reported a free and immobilized Lecitase ${ }^{\mathrm{TM}}$ Ultra-catalyzed kinetic resolution of (E)-4-arylbut-3-en-2-yl esters via their enantioselective hydrolysis $[33,34]$. Taking into consideration the activity of LU towards the synthesis of flavor esters by esterification or transesterification of alcohols $[39,55,61]$, in this work we decided to employ LU for the kinetic resolution of racemic alcohols with the 4-arylbut-3-en-2-ol system in 
the process of transesterification. To the best of our knowledge, this application of LU has not been reported yet.

\section{Results and Discussion}

\subsection{Comparison of Immobilized Preparations of Lecitase ${ }^{\mathrm{TM}}$ Ultra as the Catalysts of Transesterification}

Since enzyme-catalyzed transesterification requires an anhydrous environment, it is not possible to use directly the commercially available aqueous Lecitase ${ }^{\mathrm{TM}}$ Ultra solution for this process. Thus, the first step of the study involved the immobilization of the enzyme on four different carriers, using methods of immobilization on the surface or inside the carrier. In the first case, LU was physically adsorbed on Supelite ${ }^{\mathrm{TM}} \mathrm{DAX}-8$ polyacrylic resin (LU-DAX), covalently bound to cyanogen bromide-activated agarose (LU-CNBr), covalently bound to bacterial cellulose that was produced by Komagataeibacter xylinus and modified with polyethyleneimine, saturated by superparamagnetic $\mathrm{Fe}_{3} \mathrm{O}_{4}$ particles, and activated by glutaraldehyde (LU-MBC). In order to entrap the enzyme inside the carrier, LU was immobilized in calcium alginate to produce LU-ALG. The activity and enantioselectivity of immobilized preparations in the process of transesterification were compared using (E)-4-phenylbut-3-en-2-ol (1a) as a model substrate, obtained previously in a two-step synthesis consisting of the Claisen-Schmidt condensation of the benzaldehyde with acetone and reduction of the obtained $\alpha, \beta$-unsaturated ketone [62]. The enzymatic reactions were carried out in diisopropyl ether (DIPE) at room temperature with vinyl propionate 2 as an acyl group donor.

All the preparations catalyzed an effective kinetic resolution of the studied substrate 1a (Table 1), and for three preparations, high enantioselectivity of the reaction was observed (E $>200)$ (Entries 1-3). Shorter reaction times (4-8 h), necessary to obtain both unreacted $(S)$-alcohol 1a and $(R)$-propionate $\mathbf{3 a}$ with high enantiomeric purity, were observed in the reactions catalyzed by the LU-DAX and LU-CNBr, compared to those catalyzed by LU-ALG and LU-MBC (48-72 h). The best kinetic resolution was achieved using LU-CNBr, and after $8 \mathrm{~h}$, it resulted in the production of $(S)$-alcohol 1a and $(R)$-ester $3 \mathbf{a}$ with $e e 94 \%$ and $>99 \%$, respectively. Extending the reaction time to $24 \mathrm{~h}$ allowed the increase of $e e$ of unreacted (S)-alcohol 1a to $97 \%$. Lower optical purity of (S)-alcohol 1a (ee 90-92\%) and still high ee of $(R)$-propionate 3a $(98 \%)$ were determined in the reactions catalyzed by LU-ALG and LU-MBC after $48 \mathrm{~h}$ and $72 \mathrm{~h}$, respectively. The lowest enantioselectivity of the process was observed when LU-DAX was used. In the case of this preparation, the reaction should be stopped before exceeding $50 \%$ conversion of the substrate (after $2 \mathrm{~h}$ ) to obtain $(R)$-propionate 3a with highest optical purity. When the reaction proceeds further, the optical purity of $(S)$-alcohol 1a increases but the enantiomeric purity of $(R)$-propionate $3 \mathbf{a}$ is reduced (Entry 4$)$.

Immobilization strategy can influence enzyme catalytic properties, including their enantiospecifity. A different enantiopreference was observed for immobilized LU during hydrolysis of racemic esters of mandelic acid. For example, LU immobilized on Immobead-350, activated by ethylenediamineglutaraldehyde groups, preferred hydrolysis of the $R$ isomer of methyl mandelate. On the contrary, the immobilization of LU on Immobead-350, activated with epoxy- or ethylenediamine-divinylsulfone groups, changed the preference for the $S$ isomer [55]. In another study, LU adsorbed on octyl-agarose hydrolyzed preferentially the (R)-isomer of 2-O-butanoyl-2-phenylacetic acid, whereas LU-CNBr exhibited an inversion of the enantiopreference, yielding (S)-mandelic acid [29]. In the studies described herein, regardless of immobilization method, no changes of enantiopreference were noticed. Comparison of specific rotation signs of obtained isomers with literature data confirmed the preference of LU, predicted on the Kazlauskas rule, towards esterification of $(R, E)-4$-phenylbut-3-en-2-ol (1a), which results in the formation of $(R)$-propionate 3a and unreacted $(S)$-alcohol 1a. 
Table 1. Transesterification of racemic (E)-4-phenylbut-3-en-2-ol (1a) catalyzed by Lecitase ${ }^{\mathrm{TM}}$ Ultra immobilized on various supports.

\begin{tabular}{|c|c|c|c|c|c|c|}
\hline$r a c-1 \mathrm{a}$ & 2 & & & & & \\
\hline Entry & Biocatalyst & $t[\mathrm{~h}]$ & $c[\%]^{1}$ & $e e_{\mathrm{s}}[\%]$ & $e e_{\mathrm{p}}[\%]$ & $E^{2}$ \\
\hline \multirow{2}{*}{1} & \multirow{2}{*}{ LU-ALG } & 48 & 48 & 90 & 98 & $>200$ \\
\hline & & 72 & 49 & 91 & 93 & 83 \\
\hline \multirow{2}{*}{2} & \multirow{2}{*}{ LU-MBC } & 48 & 27 & 36 & $>99$ & $>200$ \\
\hline & & 72 & 49 & 92 & 98 & $>200$ \\
\hline \multirow{3}{*}{3} & \multirow{3}{*}{ LU-CNBr } & 4 & 47 & 89 & $>99$ & $>200$ \\
\hline & & 8 & 49 & 94 & $>99$ & $>200$ \\
\hline & & 24 & 50 & 97 & $>99$ & $>200$ \\
\hline \multirow{2}{*}{4} & \multirow{2}{*}{ LU-DAX } & 2 & 48 & 87 & 96 & 140 \\
\hline & & 4 & 52 & 94 & 88 & 55 \\
\hline
\end{tabular}

${ }^{1}$ Conversion, $c=e e_{\mathrm{s}} /\left(e e_{\mathrm{s}}+e e_{\mathrm{p}}\right) .{ }^{2}$ The enantiomeric ratio calculated at the highest conversion rate according to the following equation: $E=\ln \left[\left(1-e e_{\mathrm{s}}\right) /\left(1+\left(e e_{\mathrm{s}} / e e_{\mathrm{p}}\right)\right] / \ln \left[\left(1+e e_{\mathrm{s}}\right) /\left(1+\left(e e_{\mathrm{s}} / e e_{\mathrm{p}}\right)\right] ; e e_{\mathrm{s}}\right.\right.$-enantiomeric excess of unreacted alcohol, $e e_{\mathrm{p}}=$ enantiomeric excess of propionate.

\subsection{Effect of Enzyme Dosage}

Considering the highest optical purity of both isomers obtained after $24 \mathrm{~h}$ of the kinetic resolution of (E)-4-phenylbut-3-en-2-ol (1a) using LU-CNBr, this preparation was selected for further research to determine the impact of different factors such as enzyme dose, a type of organic solvent, and a type of an acyl donor on the process efficiency.

The first of these experiments was aimed at determining the minimum dose of the enzyme that is necessary to achieve the effective resolution of alcohol 1a (Figure 1).

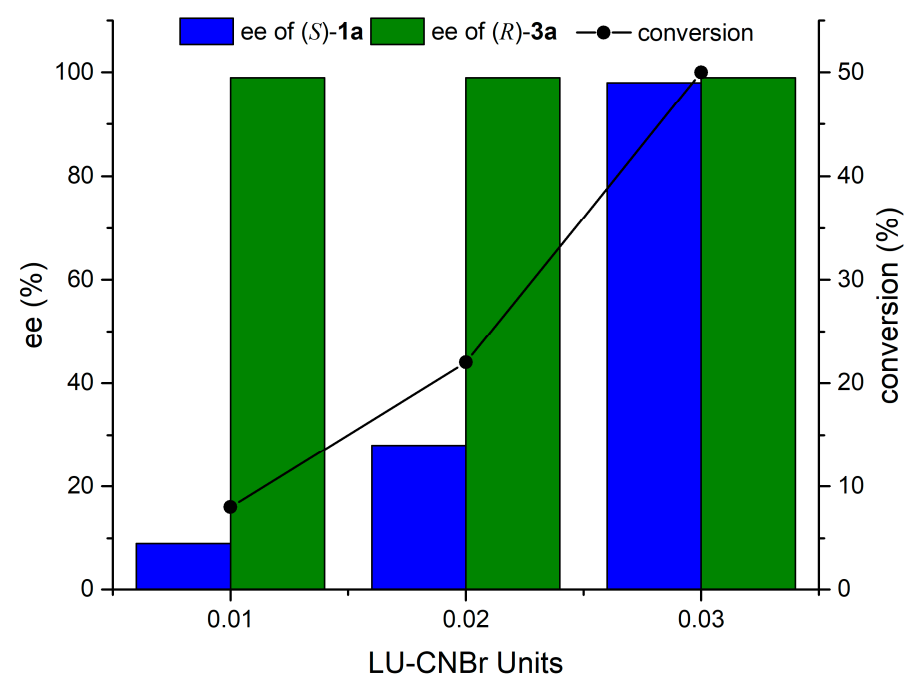

Figure 1. Effect of the cyanogen bromide (LU-CNBr) dose on the substrate conversion and optical purity of the products of kinetic resolution of racemic alcohol 1a in the process of transesterification with vinyl propionate ( $24 \mathrm{~h}$ reaction in diisopropyl ether). 
Regardless of the number of enzyme units used for the reaction, the enantioselectivity of the reaction was very high $(\mathrm{E}>200)$. The lowest effective dose of the LU-CNBr, which allowed the achievement of about $50 \%$ of substrate conversion and high enantiomeric excesses of both the obtained ester 3a (99\%) and unreacted alcohol 1a (97\%), was $0.03 \mathrm{U}$ of preparation. Lower amounts of the biocatalyst resulted in a significantly lower degree of substrate conversion, hence a clearly reduced enantiomeric purity of unreacted alcohol $\mathbf{1 a}$.

\subsection{Effect of Solvent}

The environment has a great impact on the catalytic properties of lipases $[63,64]$. These enzymes, which in natural conditions act at the water-organic phase interface, also show catalytic activity in organic solvents [65]. Polar organic solvents, e.g., methanol or DMSO, are far more enzyme-deactivating than more hydrophobic solvents. They disrupt the hydrophobic interactions responsible for the natively folded structure of proteins and strip off the water from protein molecules, which is crucial for maintaining the structure, stability, and activity of the enzymes. These factors lead to a decrease in enzyme stability that can result in denaturation [66]. Therefore, in the lipase-catalyzed reactions employed in organic synthesis, apolar solvents such as ethers, alkanes, cycloalkanes, and aromatic hydrocarbons are generally used [67].

To check the influence of the solvent on the transesterification of 4-phenylbut-3-en-2-ol (1a) with vinyl propionate and with LU-CNBr as the biocatalyst, the process was carried out for $24 \mathrm{~h}$ in six organic solvents commonly used in the lipase-catalyzed kinetic resolution of racemates (Figure 2).

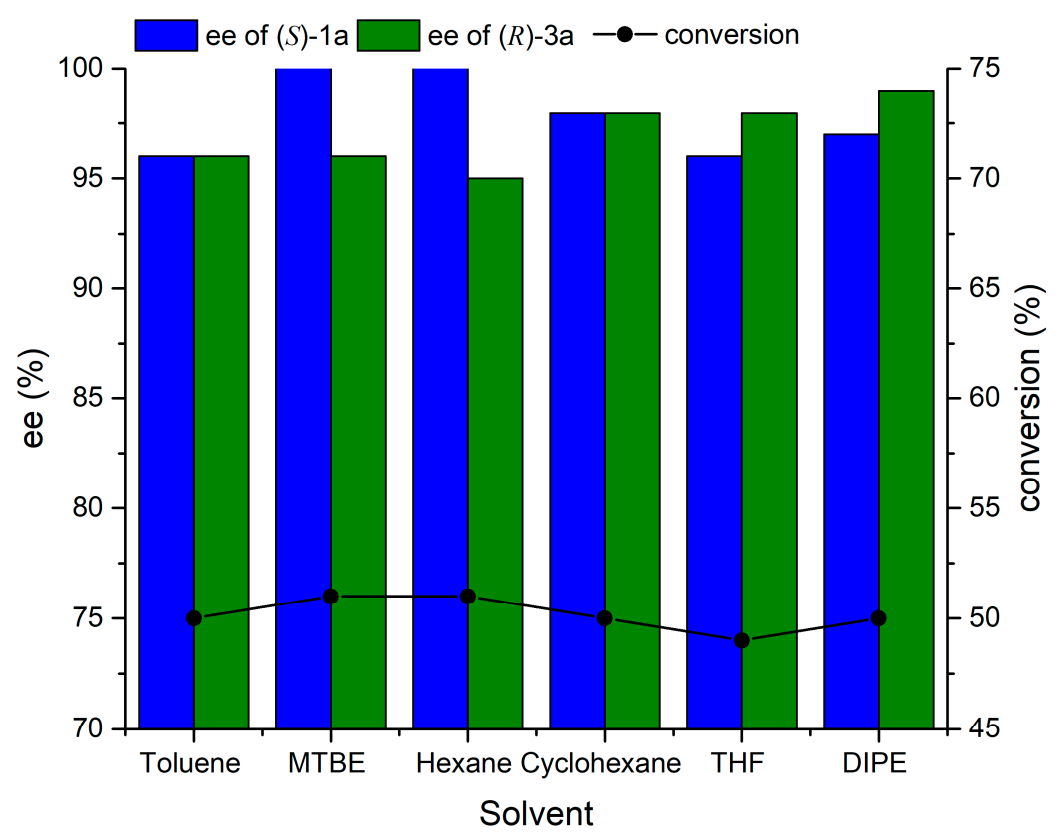

Figure 2. The effect of organic solvents on the kinetic resolution of racemic alcohol 1a in the process of transesterification with vinyl propionate catalyzed by LU-CNBr ( $24 \mathrm{~h}$ reaction, $0.06 \mathrm{U}$ of enzyme).

No significant differences were observed in the activity between the analyzed solvents. For all of them, about $50 \%$ conversion of the substrate and high enantioselectivity ( $E>200)$ were obtained, resulting in very high ee of propionate $3 \mathbf{a}$ and unreacted alcohol 1a (95-100\%). The lower enantiomeric excesses of both isomers were determined in toluene $\left(e e_{\mathrm{s}}=e e_{\mathrm{p}}=96 \%\right)$, compared with those obtained in cyclohexane $\left(e e_{\mathrm{s}}=e e_{\mathrm{p}}=98 \%\right)$. Optically pure alcohol 1a and propionate 3a with $e e 95-96 \%$ were obtained in the reactions carried out in hexane and methyl $t$-butyl ether (MTBE). In turn, the use of tetrahydrofuran (THF) and DIPE resulted in slightly higher optical purity of the resulting propionate 3a (ee 98-99\%) compared to the unreacted alcohol 1a (ee 96-97\%). 
One of the main criteria for solvent selection in the enzymatic reactions is hydrophobicity, which is measured by the logarithm of the partition coefficient between octanol and water (log P). It is generally regarded that the activity and enantioselectivity of enzymes is low in solvents with a $\log \mathrm{P}<2$, average in solvents with $\log \mathrm{P}$ between 2 and 4, and high when $\log \mathrm{P}$ exceeds 4 [68]. In the performed experiment, a panel of solvents with a wide range of polarity was tested, including hexane $(\log \mathrm{P}=3.5)$, cyclohexane ( $\log P=3.2)$, toluene $(\log P=2.5)$, DIPE $(\log P=1.52)$, MTBE $(\log P=1.3)$, and THF $(\log \mathrm{P}=0.49)$. No clear correlation between the hydrophobicity of the solvent and the catalytic activity and enantioselectivity of the reaction was found. Very high enantiomeric purity of the resolution products was achieved both in reactions carried out in aliphatic or aromatic hydrocarbon solvents (hexane, cyclohexane, toluene) and more polar ether solvents (MTBE, DIPE, THF). These results confirm that $\log \mathrm{P}$ cannot be the only criterion for a solvent selection in enzymatic reactions and other important aspects should also be taken into account, including the solubility of the substrate and the possible negative effect of the solvent on the carrier.

\subsection{Effect of Acyl Donor}

The type of acyl group donor has a great influence on the course of transesterification processes [69]. To achieve a satisfactory alcohol conversion and high optical purity of the kinetic resolution products in a relatively short time, the reaction should be irreversible. For this reason, the most widely used acyl donors are enol esters, because the immediate tautomerization of the resulting enol to the carbonyl compound shifts the equilibrium of the esterification reaction towards product formation, making the process irreversible [70]. The common reagents from this group are vinyl esters [71-75], but the activity of many lipases is inhibited as a result of imines formation in the reaction between amino groups of the lysine residues and acetaldehyde, a product of tautomerization of vinyl alcohol formed during transesterification. The solution of this inconvenience is the use of isopropenyl esters because released propen-2-ol isomerizes to acetone, which does not affect the lipase activity [76,77].

To check the effect of an acyl donor on the enantioselectivity of the reaction catalyzed by the LU-CNBr, transesterification of (E)-4-phenyl-but-3-en-2-ol was carried out using three commonly used enol esters: two vinyl esters with different acyl chain length (vinyl acetate 4 and vinyl propionate 2) and isopropenyl acetate 5 . They have been successfully used as donors of acyl groups in the kinetic resolution of racemic alcohols with the $(E)$-4-arylbut-3-en-2-ol system catalyzed by commercially available lipases [58,78-82].

All tested reagents proved to be effective acylating agents (Figure 3). The use of vinyl propionate (2) resulted in 50\% substrate conversion, and unreacted alcohol 1a and propionate 3a were obtained with $e e$ $97 \%$ and $99 \%$, respectively. In the reactions with vinyl acetate (4) and isopropenyl acetate (5), substrate conversion exceeded $50 \%$, allowing the obtainment of optically pure alcohol 1a. Higher enantiomeric excess of obtained ester $6(96 \%)$ was observed using isopropenyl acetate, compared to that achieved with vinyl acetate $(92 \%)$.

In the area of research on the kinetic resolution of alcohols with the (E)-4-arylbut-3-en-2-ol system, a significant effect of the type of enol ester on the activity and enantioselectivity of the process was previously reported for the transesterification of (E)-4-(benzo[d] $\left[1^{\prime}, 3^{\prime}\right]$ dioxol-5'-yl)-but-3-en-2-ol, catalyzed by commercially available lipases [81]. The use of isopropenyl acetate reduced the reaction rate and the degree of substrate conversion, which, in the case of the reaction catalyzed by lipase $B$ from Candida antarctica, resulted in an increase of $e e$ for unreacted $(S)$-alcohol and the resulting $(R)$-ester, from $78 \%$ and $83 \%$ to $>99 \%$ and $91 \%$, respectively, compared with the reaction in which the acyl donor was vinyl propionate. In the studies described herein, no similar effect was found, and the kinetic resolution was not significantly influenced by acyl donors. These results proved a high versatility of LU-CNBr towards common enol esters. Irrespective of the acylating agent, both isomers obtained by kinetic resolution possessed high enantiomeric purity. 
<smiles>CC(O)/C=C/c1ccccc1</smiles>

rac-1a<smiles>[R]C(=O)OC([R])=S</smiles>

$2,4,5$<smiles>[R]C(=O)OC(C)/C=C/c1ccccc1</smiles>

(R)-3a,6<smiles>C[C@H](O)/C=C/c1ccccc1</smiles>

(S)-1a

$$
\begin{aligned}
& \text { 2: } R=E t, R^{1}=H \\
& \text { 4: } R=M e, R^{1}=H \\
& \text { 5: } R, R^{1}=M e
\end{aligned}
$$

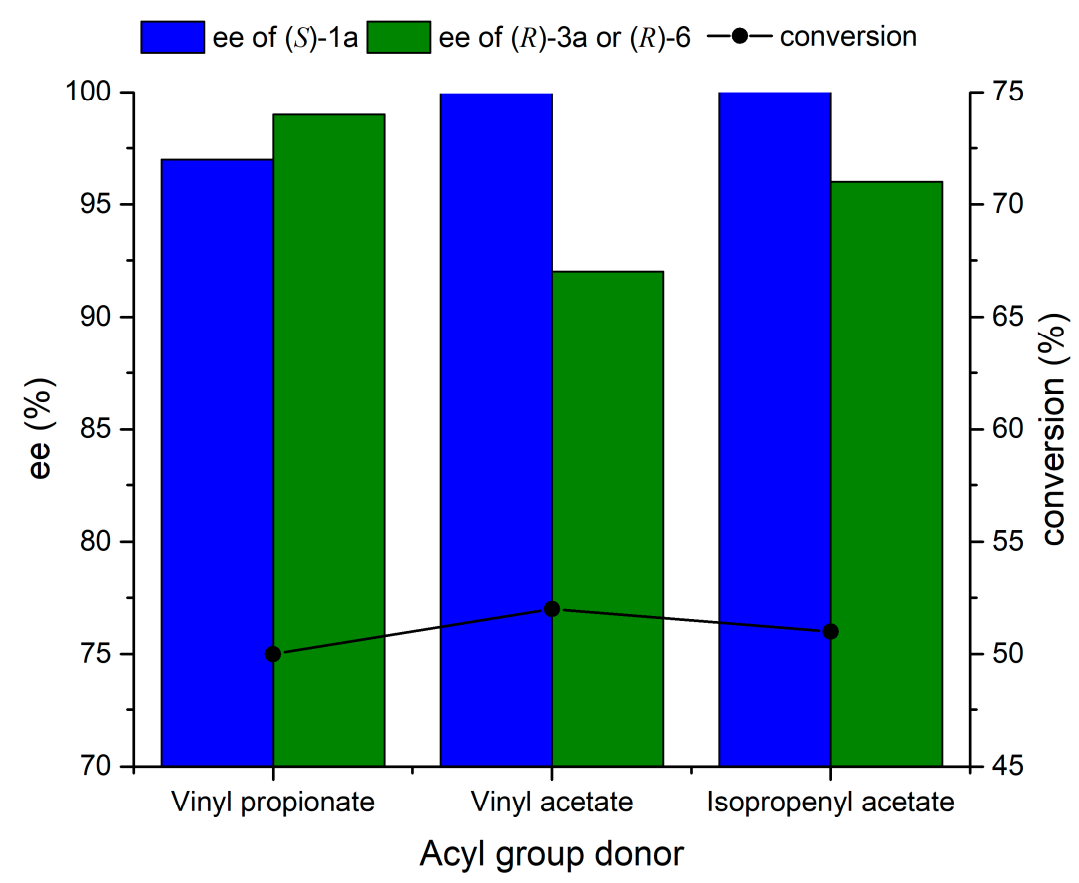

Figure 3. The effect of the acyl donor on the kinetic resolution of racemic alcohol 1a in the process of transesterification catalyzed by LU-CNBr (24 h reaction in DIPE, $0.06 \mathrm{U}$ of enzyme).

\subsection{Enzyme Reuse}

The possibility of recovery and multiple uses of the biocatalyst is one of the most important advantages of immobilized enzymes. Due to the very good results of the kinetic resolution of (E)-4-phenylbut-3-en-2-ol (1a) by LU-CNBr, the operational stability and the possibility of reuse of this biocatalyst in this process were checked. After each reaction, the enzyme was separated by filtration, residual solvent was removed, and the biocatalyst was applied to the resolution of a new substrate portion. For each reaction cycle, the conversion of alcohol 1a, enantiomeric excesses of both kinetic resolution products, and the residual activity of LU-CNBr were determined. The results are shown in Figure 4.

After two subsequent reaction cycles, LU-CNBr retained $97 \%$ of its initial activity, which correlated with a very high enantiomeric purity of both isomers produced by kinetic resolution of alcohol $\mathbf{1 a}$ (96-99\%). A rapid drop in residual activity (77\% of its initial value), was observed after the third use of the enzyme, which in the next cycle, correlated with a slightly lower degree of substrate conversion $(47 \%)$ and a lower enantiomeric excess of unreacted alcohol 1a (84\%). After the fourth reaction cycle, the activity of the preparation was reduced to almost half of its initial value, and the very low degree of substrate conversion made the kinetic resolution of alcohol 1a ineffective. 


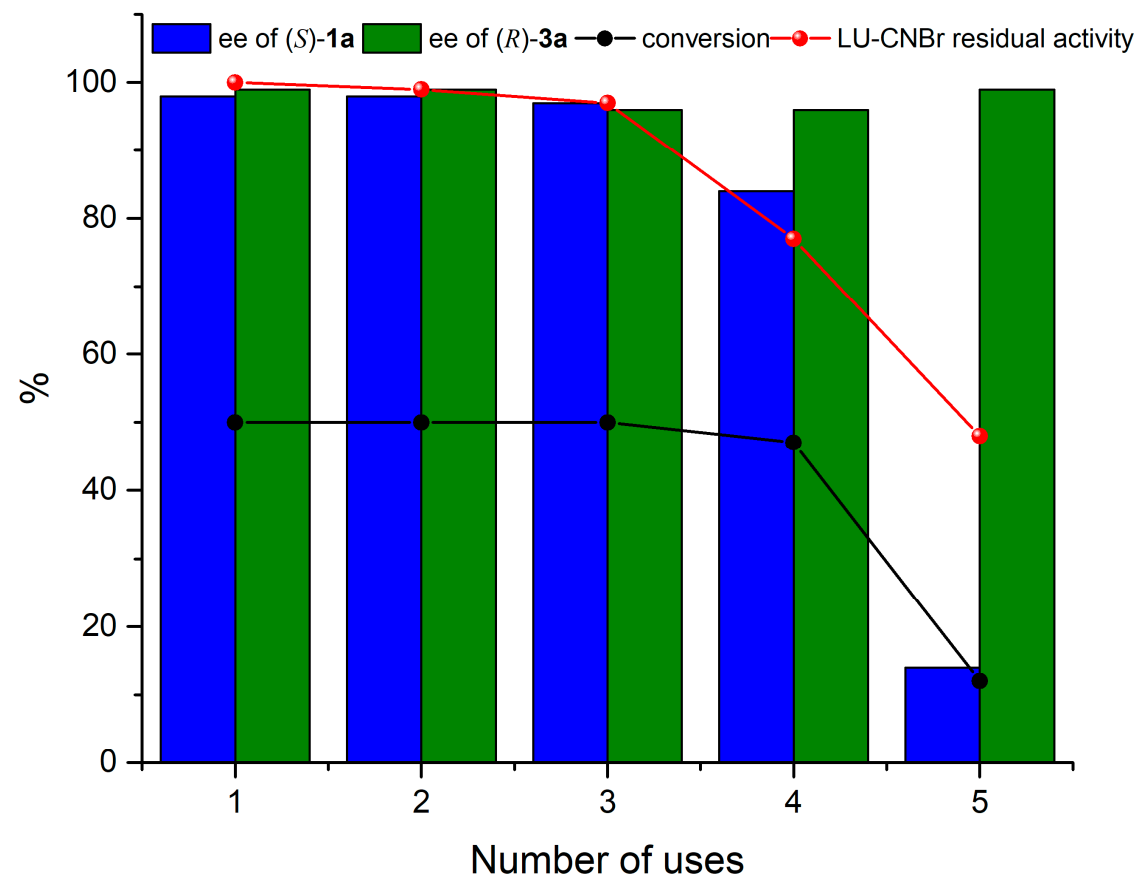

Figure 4. Operational stability of LU-CNBr and the parameters of the kinetic resolution of racemic (E)-4-phenylbut-2-en-3-ol (1a) in the process of transesterification in subsequent reaction cycles $(24 \mathrm{~h}$ reactions with vinyl propionate in DIPE, $0.06 \mathrm{U}$ of enzyme).

The activity of the LU-CNBr, expressed in units of enzymatic activity (U), is a reflection of the hydrolytic activity of enzymes towards $p$-nitrophenyl palmitate, while the degree of conversion is a measure of the activity in the process of transesterification of $(E)-4$-phenylbut-3-en-2-ol. The results indicate that the enzyme retains high esterification activity longer than hydrolytic activity. The decrease of the activity may be the result of partial denaturation of the enzyme [38], but changes in the protein conformation have a greater influence on the substrate fitting to the enzyme active site in the case of $p$-nitrophenyl palmitate than of (E)-4-phenylbut-3-en-2-ol. To date, there is no data on the operational stability of the LU in the kinetic resolution of racemic mixtures. Such studies have been carried out so far in the case of LU immobilized in a copolymer of styrene and divinylbenzene, catalyzing the esterification of myristic and caprylic acid with ethanol [39]. The activity of the preparation in this reaction decreased in subsequent reaction cycles, resulting in a complete lack of activity after the sixth cycle. In turn, for LU immobilized on Amberlite XAD2 and XAD4 resins, and used in the esterification reaction of 1,2-O-isopropylidene glycerol, a rapid decrease in activity was observed after the first reaction cycle [49]. Our results indicate that $\mathrm{LU}-\mathrm{CNBr}$ can be used three times as an effective biocatalyst in the process of kinetic resolution of (E)-4-phenylbut-3-en-2-ol (1a).

\subsection{Resolution of (E)-4-Phenylbut-3-en-2-ol Analogues (1b-d)}

In the last experiment, the immobilized LU-CNBr was used for the kinetic resolution of (E)-4-phenylbut-3-en-2-ol analogues with various substituents on the aromatic ring, such as the methyl group in the para position (alcohol 1b), two methyl groups in the 2 and 5 positions (alcohol 1c), and a methoxy group in the para position (alcohol 1d) (Table 2). Similarly to alcohol 1a, they were synthesized previously from corresponding aromatic aldehydes via Claisen-Schmidt condensation with acetone, followed by the reduction of a carbonyl group [81-83].

The presence of substituents on the aromatic ring affected the rate of transesterification of the tested alcohols and their kinetic resolution differently. The time necessary for reaching about $50 \%$ conversion was shorter for the derivative with the $p$-methylphenyl substituent $\mathbf{1 b}(6 \mathrm{~h})$, while the effective transesterification of alcohol containing the methoxy group $1 \mathrm{~d}$ required $24 \mathrm{~h}$. Enantioselectivity 
of transesterification of alcohols with methyl substituents on the benzene ring $(\mathbf{1 b}, \mathbf{1 c})$ was as high as the enantioselectivity of transesterification observed for (E)-4-phenylbut-3-en-2-ol (1a) (E > 200, Table 1), and enantiomerically pure $(R)$-propionates $3 \mathbf{b}, \mathbf{c}$ were obtained. Higher optical purity of unreacted alcohol (95\% vs. $91 \%$ ) was observed for the substrate with the 2,5-dimethylphenyl substituent (1c) than its $p$-methylsubstituted analog $(\mathbf{1 b})$. The presence of the methoxy group on the aromatic ring resulted in a lower enantioselectivity and lower optical purity of both isomers $\left(e e_{\mathrm{s}}=e e_{\mathrm{p}}=90 \%\right)($ Entry 3$)$. In all cases, the signs of specific rotations of obtained isomers (Section 3.8.4) confirmed the $R$ configuration of propionates $\mathbf{3 b}$-d and $S$ configuration of unreacted alcohols $\mathbf{1} \mathbf{b}$-d.

Table 2. Transesterification of (E)-4-arylbut-3-en-2-ols (1b-d) with different substituents on a benzene ring catalyzed by LU-CNBr.

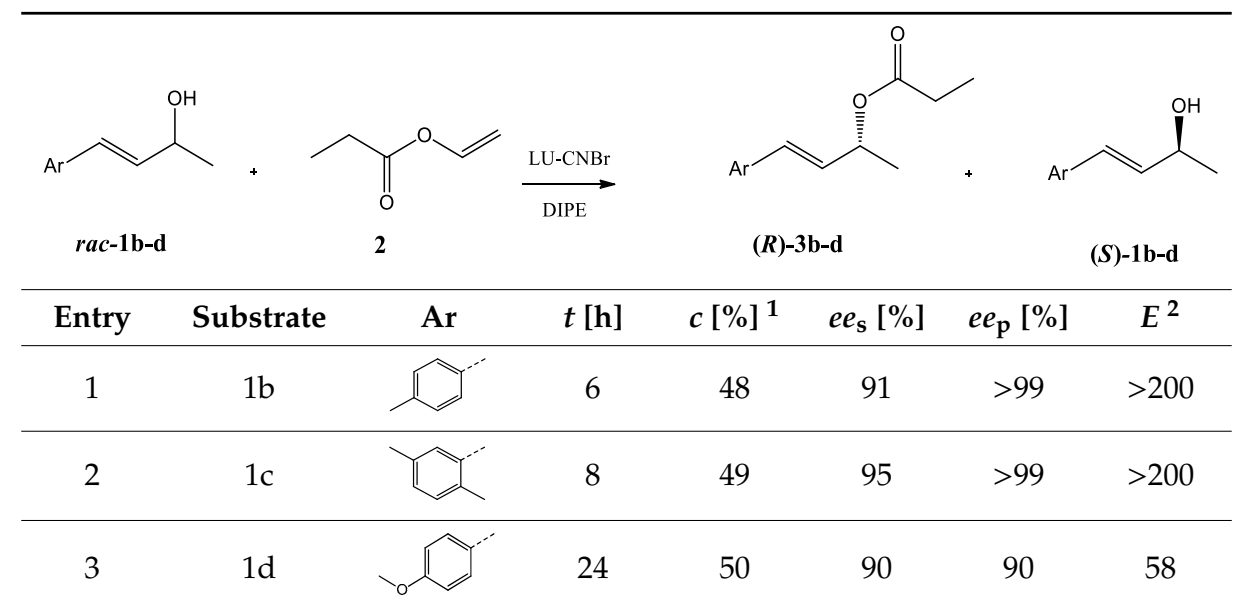

${ }^{1}$ Conversion, $c=e e_{\mathrm{s}} /\left(e e_{\mathrm{s}}+e e_{\mathrm{p}}\right) .{ }^{2}$ The enantiomeric ratio calculated at the highest conversion rate according to the following equation: $E=\ln \left[\left(1-e e_{\mathrm{s}}\right) /\left(1+\left(e e_{\mathrm{s}} / e e_{\mathrm{p}}\right)\right] / \ln \left[\left(1+e e_{\mathrm{s}}\right) /\left(1+\left(e e_{\mathrm{s}} / e e_{\mathrm{p}}\right)\right] ; e e_{\mathrm{s}}\right.\right.$ - enantiomeric excess of unreacted alcohol, $e e_{\mathrm{p}}=$ enantiomeric excess of ester.

In our previous studies on the hydrolysis of (E)-4-arylbut-3-en-2-yl esters, a similar effect of the substituents on the benzene ring on the activity and enantioselectivity of the reaction catalyzed by LU-CNBr has been shown [34]. Similar to the hydrolysis reaction, the best resolution in the process of transesterification was observed for substrates with unsubstituted benzene ring and with a 2,5-dimethylphenyl substituent; very good results were also obtained for compounds with a $p$-methylphenyl substituent. Noteworthy is the significantly shorter time $(6-8 \mathrm{~h})$ needed for effective separation of alcohols $\mathbf{1 b}$ and $\mathbf{1 c}$ by transesterification compared to the hydrolysis of their butyrates (24-48 h) [34]. In contrast to the non-enantioselective hydrolysis of butyrate containing a methoxy substituent on a benzene ring [34], transesterification of alcohol bearing this substituent (1d) was enantioselective and it was possible to obtain both products with relatively high enantiomeric excess.

\section{Materials and Methods}

\subsection{Chemicals and Enzyme}

Racemic alcohols 1a-d were synthesized from corresponding aromatic aldehydes as described earlier $[62,81,83]$. Cyanogen bromide-activated $4 \%$ agarose (Sepharose ${ }^{\circledR} 4 \mathrm{~B}$ ) was purchased from GE Healthcare Bio-Sciences AB (Uppsala, Sweden). Phospholipase $\mathrm{A}_{1}$ from Aspergillus oryzae (Lecitase $^{\mathrm{TM}}$ Ultra, LU), $p$-nitrophenyl palmitate ( $p$-NPP, $\geq 98 \%$ ), $p$-nitrophenol ( $p$-NP, spectrophotometric grade), vinyl acetate ( $\geq 99 \%)$, vinyl propionate $(98 \%)$, isopropenyl acetate $(99 \%)$, and sodium alginate were bought from Sigma-Aldrich (St. Louis, MO, USA). Supelite ${ }^{\mathrm{TM}}$ DAX-8 was purchased from Supelco Analytical (Bellefonte, PA, USA). 


\subsection{Analysis}

Products of enzymatic reactions were analyzed by chiral gas chromatography (CGC, examples of chromatograms are presented in Fig. S9-S12) on an Agilent Technologies 6890 N instrument (Santa Clara, CA, USA) using CP-Chirasil-Dex CB column ( $25 \mathrm{~m} \times 0.25 \mathrm{~mm} \times 0.25 \mu \mathrm{m}$, Agilent, Palo Alto, CA, USA). The temperature program: injector $280^{\circ} \mathrm{C}$, detector (FID) $280^{\circ} \mathrm{C}$, column $80-130{ }^{\circ} \mathrm{C}\left(0.5^{\circ} \mathrm{C} \mathrm{min}{ }^{-1}\right)$, $130-200{ }^{\circ} \mathrm{C}\left(30^{\circ} \mathrm{C} \mathrm{min}{ }^{-1}\right), 200{ }^{\circ} \mathrm{C}(2 \mathrm{~min})$. Preparative Thin-Layer Chromatography on silica gel glass plates (Uniplate ${ }^{\mathrm{TM}} \mathrm{UV} 254$, layer thickness $1000 \mu \mathrm{m}, 20 \mathrm{~cm} \times 20 \mathrm{~cm}$, Analtech, Newar, DE, USA) was applied to separate alcohols $\mathbf{1 a - d}$ and propionates $\mathbf{3 a - d}$. The plates were sprayed by a solution of $1 \% \mathrm{Ce}\left(\mathrm{SO}_{4}\right)_{2}$ and $2 \% \mathrm{H}_{3}\left[\mathrm{P}\left(\mathrm{Mo}_{3} \mathrm{O}_{10}\right)_{4}\right]$ in $10 \% \mathrm{H}_{2} \mathrm{SO}_{4}$ to visualize the compounds. Spectrophotometric measurements were made on a Cintra 101 apparatus (GBC Scientific equipment, Dandenong, Australia) at $410 \mathrm{~nm}$.

\subsection{Enzymatic Activity Assays}

Activity of the immobilized LU preparations was determined using $p$-NP assay [84]. The reaction mixture contained $75 \mu \mathrm{L}$ of $p$-NPP isopropyl alcohol solution $(1 \mathrm{mM}), 5.75 \mathrm{~mL}$ of $10 \mathrm{mM}$ Tris/HCl buffer ( $\mathrm{pH} 8.0$ ), and $30 \mathrm{mg}$ of immobilized enzyme. After $30 \mathrm{~min}$ of incubation at $37^{\circ} \mathrm{C}, 1 \mathrm{~mL}$ of cold ethanol was added to quench the reaction and the enzyme was allowed to settle. The clear supernatant was transferred to cuvettes of the spectrophotometer and absorbance of the samples was measured spectrophotometrically against a blank sample (without the enzyme). The amount of $p$-NP was calculated using a standard curve prepared for $p$-NP in the concentration range of $0-0.3 \mathrm{mM}$. Activity of immobilized enzymes was expressed in units per gram of immobilized enzyme $(\mathrm{U} / \mathrm{g})$, where one unit corresponds to an amount of enzyme that liberated $1 \mu \mathrm{mol}$ of $p$-NP per minute under the conditions described.

\subsection{Immobilization of LU in Calcium Alginate Beads}

The mixture of Lecitase ${ }^{\mathrm{TM}}$ Ultra solution $(2.2 \mathrm{~mL})$ and $6 \%(w / v)$ solution of sodium alginate $(10 \mathrm{~mL})$ was stirred for $1 \mathrm{~h}$ and dropped through a syringe into $500 \mathrm{~mL}$ of $0.3 \mathrm{M} \mathrm{CaCl}_{2}$ solution. After $1 \mathrm{~h}$ of hardening, the beads were filtered and washed with distilled water. After $24 \mathrm{~h}$ of freeze-drying using an LYO GT2 Freeze Dryer (SEIB Industrie, Goeteborg, Sweden), the immobilized beads of Lecitase ${ }^{\mathrm{TM}}$ Ultra $(0.04 \mathrm{U} / \mathrm{g})$ were collected and stored at $4{ }^{\circ} \mathrm{C}$ until use.

\subsection{Adsorption of LU on Polyacrylic Resin (Supelite ${ }^{\mathrm{TM}} \mathrm{DAX}-8$ )}

Supelite ${ }^{\mathrm{TM}} \mathrm{DAX}-8$ was washed with the Tris-HCl buffer followed by distilled water $(4 \times 20 \mathrm{~mL})$ and dried for $24 \mathrm{~h}$ at room temperature. Lecitase ${ }^{\mathrm{TM}}$ Ultra $(4 \mathrm{~mL})$ in $10 \mathrm{~mL}$ of the Tris-HCl buffer was shaken for $24 \mathrm{~h}$ with a $1 \mathrm{~g}$ of pretreated Supelite ${ }^{\mathrm{TM}} \mathrm{DAX}-8$ in a twisted $20 \mathrm{~mL}$ vial using an end-over-end shaker. The immobilized enzyme $(0.06 \mathrm{U} / \mathrm{g})$ was filtered, washed with the Tris-HCl buffer $(2 \times 10 \mathrm{~mL})$, freeze-dried for $24 \mathrm{~h}$, and stored at $4{ }^{\circ} \mathrm{C}$ until use.

\subsection{Immobilization of LU on Cyanogen Bromide-Activated Crosslinked 4\% Agarose}

Commercial Lecitase ${ }^{\mathrm{TM}}$ Ultra $(2 \mathrm{~mL}), 12 \mathrm{~mL}$ of the coupling buffer $\left(0.1 \mathrm{M} \mathrm{NaHCO}_{3}, \mathrm{pH} 8.3\right)$ containing $0.5 \mathrm{M} \mathrm{NaCl}$, and $3 \mathrm{~g}$ of wet cyanogen bromide were shaken on a rotary shaker for $1 \mathrm{~h}$ at $20^{\circ} \mathrm{C}$. The immobilized enzyme $(0.06 \mathrm{U} / \mathrm{g})$ was filtered on a Schott G3 funnel, washed with $50 \mathrm{~mL}$ of the coupling buffer, resuspended at $1 \mathrm{M}$ ethanolamine $(\mathrm{pH} 8.0)$, and incubated for $2 \mathrm{~h}$ at $20^{\circ} \mathrm{C}$. Then, it was filtered and washed with an acetate buffer $(\mathrm{pH} 4.0,40 \mathrm{~mL})$ followed by the coupling buffer $(50 \mathrm{~mL})$, freeze-dried for $24 \mathrm{~h}$, and stored at $4{ }^{\circ} \mathrm{C}$ until use.

\subsection{Immobilization of LU on Modified Bacterial Cellulose}

The details of the carrier preparation and immobilization procedure were described previously [56]. Briefly, magnetic bacterial cellulose spheres modified by polyethyleneimine were activated by $1 \%$ 
glutaraldehyde solution in $100 \mathrm{mM}$ of a phosphate buffer (pH 7.0). In the next step, $5 \mathrm{~mL}$ of activated carrier were mixed with $10 \mathrm{~mL}$ of commercial preparation Lecitase ${ }^{\mathrm{TM}}$ Ultra and incubated for $24 \mathrm{~h}$ at $4{ }^{\circ} \mathrm{C}$ at a roller shaker. After incubation time, the immobilized enzyme was separated by using a magnetic separator, thoroughly washed with the phosphate buffer, and incubated with buffered $\mathrm{NaBH}_{4}$ solution at $4{ }^{\circ} \mathrm{C}$ for $1 \mathrm{~h}$. Next, the preparation was collected by using the magnetic separator and flushed with the phosphate buffer containing $100 \mathrm{mM} \mathrm{NaCl}$ and $0.25 \%$ Triton-X100. Finally, the preparation $(0.045 \mathrm{U} / \mathrm{g})$ was washed again by the phosphate buffer, freeze-dried for $24 \mathrm{~h}$ and stored at $4{ }^{\circ} \mathrm{C}$ until use.

\subsection{Enzymatic Transesterification of Racemic Alcohols 1a-d Catalyzed by Immobilized LU Preparations}

\subsubsection{General Procedure}

Racemic alcohol 1a-d $(0.2 \mathrm{~g})$ and $2 \mathrm{~mL}$ of acyl donor (2,4 or 5) were dissolved in $6 \mathrm{~mL}$ of organic solvent followed by the addition of immobilized Lecitase ${ }^{\mathrm{TM}}$ Ultra $(0.06 \mathrm{U})$. Reactions were carried out in $10 \mathrm{~mL}$ screw-cap glass vials on a magnetic stirrer $(750 \mathrm{rpm})$ at room temperature. Samples $(0.6 \mathrm{~mL})$ were taken from the reaction mixture at the specified intervals and filtered through Celite 560 using diethyl ether to wash the adsorbent bed. After removal of excess solvent using a rotary vacuum evaporator, the concentrated samples were analyzed on a GC chiral column. Prior to GC analysis, the samples were treated with acetyl or propionyl chloride to derivatize inseparable enantiomers of alcohols 1a-d into corresponding esters according to the procedure described elsewhere [82]. Following this general protocol, the effect of the solvent and acyl donor on the transesterification of rac-(E)-4-phenylbut-3-en-2-ol (1a) using LU-CNBr was investigated.

\subsubsection{Effect of Enzyme Dosage}

Transesterification of racemic alcohol 1a $(0.1 \mathrm{~g})$ in DIPE $(3 \mathrm{~mL})$ was carried out for $24 \mathrm{~h}$ as described in Section 3.8.1 using different doses of LU-CNBr (0.01 U, $0.02 \mathrm{U}$ and $0.03 \mathrm{U})$ and $2 \mathrm{~mL}$ of vinyl propionate.

\subsubsection{Enzyme Reusability}

Racemic (E)-4-phenylbut-3-en-2-ol (1a) was subjected to the transesterification using LU-CNBr according to the procedure described in Section 3.8.1. After the reaction, the enzyme preparation was recovered by filtration and dried at room temperature to remove the residual solvents. The residual activity of the recovered enzyme was measured as described in Section 3.3 and the enzyme was used as a biocatalyst in the next reaction cycle, with a fresh portion of substrate 1a. Totally, the enzyme was used in five reaction cycles.

\subsubsection{Isolation of Products Obtained by Transesterification of Racemic Alcohols (1a-d) - General Procedure}

Transesterification of racemic alcohols 1a-d $(0.2 \mathrm{~g})$ in DIPE $(6 \mathrm{~mL})$ was carried out for $24 \mathrm{~h}$ as described in Section 3.8.1, using $0.06 \mathrm{U}$ of LU-CNBr and $2 \mathrm{~mL}$ of vinyl propionate. Reaction mixtures were filtered through Celite 560 and the organic solvent was evaporated under vacuo. Products were separated by preparative TLC (hexane:acetone, 10:1). They were known from previous literature reports and their spectroscopic data $\left({ }^{1} \mathrm{H} N M R,{ }^{13} \mathrm{C} N M R\right.$, IR) were consistent with those reported earlier $[81,82,85]$. For confirmation of the structures, ${ }^{1} \mathrm{H}$ NMR spectra of the products were included in Supplementary Materials (Figures S1-S8).

Transesterification of alcohol 1a $(0.2 \mathrm{~g}, 1.3 \mathrm{mmol})$ afforded the products:

$(-)-(S, E)-4-$ phenylbut-3-en-2-ol ((S)-1a): yield 45\% (0.09 g), $\mathrm{R}_{\mathrm{f}}=0.23$ [hexane/acetone $\left.(4: 1 \mathrm{v} / \mathrm{v})\right]$, $\mathrm{t}_{\mathrm{R}}=35.19 \mathrm{~min}$ (after derivatization to acetate), ee $97 \%,[\alpha]_{D}^{20}=-19.0$ (c 1.38; $\mathrm{CH}_{2} \mathrm{Cl}_{2}$ ), lit. [82]: $[\alpha]_{D}^{20}=-23.7$ (c 2.6; $\mathrm{CH}_{2} \mathrm{Cl}_{2}$, ee $>99 \%$ )

(+)-(R,E)-4-phenylbut-3-en-2-yl propionate $((R)-3 a)$ : yield $40 \%(0.109 \mathrm{~g}), \mathrm{R}_{\mathrm{f}}=0.64$ [hexane/acetone $\left.(4: 1 \mathrm{v} / \mathrm{v})\right]$, $\mathrm{t}_{\mathrm{R}}=43.66 \mathrm{~min}$, ee $>99 \%,[\alpha]_{D}^{20}=+115.7$ (c 1.15; $\mathrm{CH}_{2} \mathrm{Cl}_{2}$ ), lit. [82]: $[\alpha]_{D}^{20}=+115.9$ (c 2.1; $\mathrm{CH}_{2} \mathrm{Cl}_{2}$, ee $99 \%$ ) 
Transesterification of alcohol $\mathbf{1 b}(0.2 \mathrm{~g}, 1.2 \mathrm{mmol})$ afforded the products:

$(-)-(S, E)-4-\left(4^{\prime}\right.$-methylphenyl)but-3-en-2-ol ((S)-1b): yield 47\% $(0.095 \mathrm{~g}), \mathrm{R}_{\mathrm{f}}=0.23$ [hexane/acetone (4:1 $v / v)], \mathrm{t}_{\mathrm{R}}=172.54 \mathrm{~min}$ (after derivatization to acetate), ee $91 \%$, $[\alpha]_{D}^{20}=-20.5$ (c 1.22; $\mathrm{CH}_{2} \mathrm{Cl}_{2}$ ), lit. [82]: $[\alpha]_{D}^{20}=-22.8$ (c $1.8 ; \mathrm{CH}_{2} \mathrm{Cl}_{2}$, ee $\left.95 \%\right)$

$(+)-(R, E)-4-\left(4^{\prime}\right.$-methylphenyl)but-3-en-2-yl propionate $((R)-3 \mathbf{b}):$ yield $45 \%(0.121 \mathrm{~g}), \mathrm{R}_{\mathrm{f}}=0.65$ [hexane/acetone $(4: 1 \mathrm{v} / v)], \mathrm{t}_{\mathrm{R}}=188.36 \mathrm{~min}$, ee $>99 \%,[\alpha]_{D}^{20}=+117.4$ (c 1.17; $\mathrm{CH}_{2} \mathrm{Cl}_{2}$ ), lit. [82]: $[\alpha]_{D}^{20}=+111.8\left(\right.$ c $1.7 ; \mathrm{CH}_{2} \mathrm{Cl}_{2}$, ee $\left.88 \%\right)$

Transesterification of alcohol 1c $(0.2 \mathrm{~g}, 1.1 \mathrm{mmol})$ afforded the products:

$(-)-(S, E)-4-\left(2^{\prime}, 5^{\prime}\right.$-dimethylphenyl)but-3-en-2-ol ((S)-1c): yield 46\% (0.091 g), $R_{\mathrm{f}}=0.24$ [hexane/acetone $(4: 1 v / v)], \mathrm{t}_{\mathrm{R}}=216.65 \mathrm{~min}$ (after derivatization to acetate), ee $95 \%,[\alpha]_{D}^{20}=-15.1$ (c 1.32; $\mathrm{CH}_{2} \mathrm{Cl}_{2}$ ), lit. [81]: $[\alpha]_{D}^{20}=-16.1$ (c $1.9 ; \mathrm{CH}_{2} \mathrm{Cl}_{2}$, ee $98 \%$ )

$(+)-(R, E)-4-\left(2^{\prime}, 5^{\prime}\right.$-dimethylphenyl)but-3-en-2-yl propionate $((R)-3 \mathrm{c})$ : yield $43 \%(0.111 \mathrm{~g}), \mathrm{R}_{\mathrm{f}}=0.67$ [hexane/acetone $(4: 1 \mathrm{v} / \mathrm{v})], \mathrm{t}_{\mathrm{R}}=244.97 \mathrm{~min}$, ee $99 \%,[\alpha]_{D}^{20}=+116.9\left(\mathrm{c} 1.15 ; \mathrm{CH}_{2} \mathrm{Cl}_{2}\right) ;$ lit. [81]: $[\alpha]_{D}^{20}=+116.8$ (c $1.6 ; \mathrm{CH}_{2} \mathrm{Cl}_{2}$, ee $98 \%$ )

Transesterification of alcohol $1 \mathbf{d}(0.2 \mathrm{~g}, 1.1 \mathrm{mmol})$ afforded the products:

(-)-(S,E)-4-(4'-methoxyphenyl)but-3-en-2-ol ((S)-1d): yield 46\% (0.092 g), $\mathrm{R}_{\mathrm{f}}=0.25$ [hexane/acetone $(4: 1 \mathrm{v} / \mathrm{v})], \mathrm{t}_{\mathrm{R}}=262.50 \mathrm{~min}$ (after derivatization to acetate), ee $90 \%$, $[\alpha]_{D}^{20}=-33.1$ (c 1.34; $\mathrm{CH}_{2} \mathrm{Cl}_{2}$ ). lit. [85]: $[\alpha]_{D}^{20}=-28.5\left(\right.$ c $1.8 ; \mathrm{CHCl}_{3}$, ee $\left.78 \%\right)$

$(+)-(R, E)-4-\left(4^{\prime}\right.$-methoxyphenyl)but-3-en-2-yl propionate $((R)-3 \mathrm{~d})$ : yield $44 \%(0.115 \mathrm{~g}), \mathrm{R}_{\mathrm{f}}=0.66$ [hexane/acetone $(4: 1 \mathrm{v} / \mathrm{v})], \mathrm{t}_{\mathrm{R}}=288.62 \mathrm{~min}$, ee $90 \%,[\alpha]_{D}^{20}=+119.1\left(\mathrm{c} 1.18 ; \mathrm{CH}_{2} \mathrm{Cl}_{2}\right) ;$ lit. [85]: $[\alpha]_{D}^{20}=+113.5$ (c 1.6; $\mathrm{CH}_{2} \mathrm{Cl}_{2}$, ee $82 \%$ )

\section{Conclusions}

The work describes for the first time the use of immobilized Lecitase ${ }^{\mathrm{TM}}$ Ultra preparations as biocatalysts for the kinetic resolution of racemic (E)-4-phenylbut-3-en-2-ol and its structural analogues by transesterification. The best results were obtained in the reaction catalyzed by the preparation immobilized on cyanogen bromide-activated agarose (LU-CNBr), which resulted in both resolution products with high yields and very high enantiomeric excesses $(\geq 96 \%)$. This preparation turned out to be an effective and versatile biocatalyst, showing high activity and enantioselectivity in a wide range of organic solvents in the presence of commonly used acyl donors. An additional advantage of this biocatalyst is an easy recovery and high operational stability, allowing for its reuse in three subsequent reaction cycles without negative effects on the efficiency and enantioselectivity of transesterification. Due to the low cost of the preparation and simple immobilization, it becomes a promising alternative to the commercially available lipases commonly used for the resolution of racemic alcohols.

Future research will focus on the determination of the substrate specificity of LU towards a variety of alcohols, as well as the use of this enzyme in unconventional reaction media (ionic liquids, eutectic solvents, supercritical liquids, etc.).

Supplementary Materials: The following are available online at: http://www.mdpi.com/2073-4344/10/7/798/s1, Figures S1-S8: ${ }^{1} \mathrm{H}$ NMR spectra of substrates (1a-d) and products of transesterifications (3a-d), Figure S9: Chromatogram from chiral GC showing traces of racemic (E)-4-phenylbut-3-en-2-ol (1a) (after derivatization into acetate) and (E)-4-phenylbut-3-en-2-yl propionate (3a), Figure S10-S12: Chromatograms from chiral GC after transesterification of racemic (E)-4-phenylbut-3-en-2-ol (1a) with vinyl propionate in DIPE using $0.01 \mathrm{U}, 0.02 \mathrm{U}$ and $0.03 \mathrm{U}$ of enzyme.

Author Contributions: Conceptualization, A.L. and W.G.; investigation, A.L., R.D., and M.S.; writing-original draft, A.L.; writing - review and editing, A.L., A.C., R.D., and W.G. All authors have read and agreed to the published version of the manuscript. 
Funding: This research was financed by the statutory activities of the Department of Chemistry, Wrocław University of Environmental and Life Sciences. Article Processing Charge (APC) was financed under the Leading Research Groups support project from the subsidy increased for the period 2020-2025 in the amount of 2\% of the subsidy referred to in Art. 387 (3) of the Law of 20 July 2018 on Higher Education and Science, obtained in 2019.

Conflicts of Interest: The authors declare no conflict of interest.

\section{References}

1. Meyer, H.P.; Eichhorn, E.; Hanlon, S.; Lütz, S.; Schürmann, M.; Wohlgemuth, R.; Coppolecchia, R. The use of enzymes in organic synthesis and the life sciences: Perspectives from the Swiss Industrial Biocatalysis Consortium (SIBC). Catal. Sci. Technol. 2013, 3, 29-40. [CrossRef]

2. Sen, S.; Puskas, J.E. Green polymer chemistry: Enzyme catalysis for polymer functionalization. Molecules 2015, 20, 9358-9379. [CrossRef]

3. Winkler, M.; Geier, M.; Hanlon, S.P.; Nidetzky, B.; Glieder, A. Human enzymes for organic synthesis. Angew. Chem. Int. Ed. 2018, 57, 13406-13423. [CrossRef] [PubMed]

4. Ran, N.; Zhao, L.; Chen, Z.; Tao, J. Recent applications of biocatalysis in developing green chemistry for chemical synthesis at the industrial scale. Green Chem. 2008, 10, 361-372. [CrossRef]

5. Robles-Medina, A.; González-Moreno, P.A.; Esteban-Cerdán, L.; Molina-Grima, E. Biocatalysis: Towards ever greener biodiesel production. Biotechnol. Adv. 2009, 27, 398-408. [CrossRef] [PubMed]

6. Ferreira-Leitão, V.S.; Cammarota, M.C.; Aguieiras, E.C.G.; de Sá, L.R.V.; Fernandez-Lafuente, R.; Freire, D.M.G. The protagonism of biocatalysis in green chemistry and its environmental benefits. Catalysts 2017, 7, 9. [CrossRef]

7. Fernández-Arrojo, L.; Guazzaroni, M.E.; López-Cortés, N.; Beloqui, A.; Ferrer, M. Metagenomic era for biocatalyst identification. Curr. Opin. Biotechnol. 2010, 21, 725-733. [CrossRef] [PubMed]

8. Reetz, M.T. Biocatalysis in organic chemistry and biotechnology: Past, present, and future. J. Am. Chem. Soc. 2013, 135, 12480-12496. [CrossRef]

9. Castilla, I.A.; Woods, D.F.; Reen, F.J.; O'Gara, F. Harnessing marine biocatalytic reservoirs for green chemistry applications through metagenomic technologies. Mar. Drugs 2018, 16, 1-21. [CrossRef]

10. Bornscheuer, U.T.; Pohl, M. Improved biocatalysts by directed evolution and rational protein design. Curr. Opin. Chem. Biol. 2001, 5, 137-143. [CrossRef]

11. Morley, K.L.; Kazlauskas, R.J. Improving enzyme properties: When are closer mutations better? Trends Biotechnol. 2005, 23, 231-237. [CrossRef]

12. Strohmeier, G.A.; Pichler, H.; May, O.; Gruber-Khadjawi, M. Application of designed enzymes in organic synthesis. Chem. Rev. 2011, 111, 4141-4164. [CrossRef] [PubMed]

13. Virgen-Ortíz, J.J.; dos Santos, J.C.S.; Ortiz, C.; Berenguer-Murcia, Á.; Barbosa, O.; Rodrigues, R.C.; Fernandez-Lafuente, R. Lecitase Ultra: A phospholipase with great potential in biocatalysis. Mol. Catal. 2019, 473, 110405. [CrossRef]

14. Clausen, K. Enzymatic oil-degumming by a novel microbial phospholipase. Eur. J. Lipid Sci. Technol. 2001, 103, 333-340. [CrossRef]

15. Manjula, S.; Jose, A.; Divakar, S.; Subramanian, R. Degumming rice bran oil using phospholipase-A 1 . Eur. J. Lipid Sci. Technol. 2011, 113, 658-664. [CrossRef]

16. Lamas, D.L.; Crapiste, G.H.; Constenla, D.T. Changes in quality and composition of sunflower oil during enzymatic degumming process. LWT-Food Sci. Technol. 2014, 58, 71-76. [CrossRef]

17. Sampaio, K.A.; Zyaykina, N.; Wozniak, B.; Tsukamoto, J.; Greyt, W.D.; Stevens, C.V. Enzymatic degumming: Degumming efficiency versus yield increase. Eur. J. Lipid Sci. Technol. 2015, 117, 81-86. [CrossRef]

18. Mardani, M.; Farmani, J.; Kenari, R.E. Efficacy of some commercial lipases in hydrolysis of palm olein for the production of free fatty acids and diacylglycerol oil. J. Oil Palm Res. 2015, 27, 250-260.

19. Wang, Y.; Zhao, M.; Song, K.; Wang, L.; Tang, S.; Riley, W.W. Partial hydrolysis of soybean oil by phospholipase $\mathrm{A}_{1}$ (Lecitase Ultra). Food Chem. 2010, 121, 1066-1072. [CrossRef]

20. Wang, Y.; Zhao, M.; Song, K.; Wang, L.; Han, X.; Tang, S.; Wang, Y. Separation of diacylglycerols from enzymatically hydrolyzed soybean oil by molecular distillation. Sep. Purif. Technol. 2010, 75, 114-120. [CrossRef] 
21. Goñi, M.L.; Pacheco, C.; Constenla, D.T.; Carelli, A.A. Solvent-free enzymatic hydrolysis of non-polar lipids in crude sunflower lecithin using phospholipase $A_{1}$ (Lecitase ${ }^{\circledR}$ Ultra). Biocatal. Biotransform. 2018, 36, 341-351. [CrossRef]

22. Liu, N.; Wang, Y.; Zhao, Q.; Zhao, M. Production of palm oil-based diacylglycerol using Lecitase Ultra-catalyzed glycerolysis and molecular distillation. Food Sci. Biotechnol. 2014, 23, 365-371. [CrossRef]

23. Wang, L.; Wang, Y.; Hu, C.; Cao, Q.; Yang, X.; Zhao, M. Preparation of diacylglycerol-enriched oil from free fatty acids using Lecitase Ultra-catalyzed esterification. J. Am. Oil Chem. Soc. 2011, 88, 1557-1565. [CrossRef]

24. Liu, N.; Wang, Y.; Zhao, Q.; Zhang, Q.; Zhao, M. Fast synthesis of 1,3-DAG by Lecitase ${ }^{\circledR}$ Ultra-catalyzed esterification in solvent-free system. Eur. J. Lipid Sci. Technol. 2011, 113, 973-979. [CrossRef] [PubMed]

25. Kim, M.J.; Han, K.L.; Park, J. (S)-selective dynamic kinetic resolution of allylic alcohols by enzyme-metal bicatalysis. Bull. Korean Chem. Soc. 2007, 28, 2096-2098.

26. Baeza-Jiménez, R.; González-Rodríguez, J.; Kim, I.H.; García, H.S.; Otero, C. Use of immobilized phospholipase $\mathrm{A}_{1}$-catalyzed acidolysis for the production of structured phosphatidylcholine with an elevated conjugated linoleic acid content. Grasas y Aceites 2012, 63, 44-52.

27. Zhao, T.; No, D.S.; Kim, B.H.; Garcia, H.S.; Kim, Y.; Kim, I.H. Immobilized phospholipase A $_{1}$-catalyzed modification of phosphatidylcholine with n-3 polyunsaturated fatty acid. Food Chem. 2014, 157, $132-140$. [CrossRef]

28. Xi, X.; Feng, X.; Shi, N.; Ma, X.; Lin, H.; Han, Y. Immobilized phospholipase A $_{1}$-catalyzed acidolysis of phosphatidylcholine from Antarctic krill (Euphausia superba) for docosahexaenoic acid enrichment under supercritical conditions. J. Mol. Catal. B Enzym. 2016, 126, 46-55. [CrossRef]

29. Fernandez-Lorente, G.; Palomo, J.M.; Guisan, J.M.; Fernandez-Lafuente, R. Effect of the immobilization protocol in the activity, stability, and enantioselectivity of Lecitase ${ }^{\circledR}$ Ultra. J. Mol. Catal. B Enzym. 2007, 47, 99-104. [CrossRef]

30. Mishra, M.K.; Harini, M.; Kumaraguru, T.; Lakshmi Prasanna, T.; Fadnavis, N.W. A porous vessel bioreactor for gel entrapped biocatalysts: Kinetic resolution of trans-methyl (4-methoxyphenyl)glycidate by Lecitase ${ }^{\circledR}$ Ultra in gelatin organogel (Gelozyme). J. Mol. Catal. B Enzym. 2011, 71, 56-62. [CrossRef]

31. Kumaraguru, T.; Harini, T.; Basetty, S. Immobilization of Lecitase ${ }^{\circledR}$ Ultra on recyclable polymer support: Application in resolution of trans-methyl (4-methoxyphenyl) glycidate in organic solvents. Tetrahedron Asymmetry 2017, 28, 1612-1617. [CrossRef]

32. Mishra, M.K.; Kumaraguru, T.; Sheelu, G.; Fadnavis, N.W. Lipase activity of Lecitase ${ }^{\circledR}$ Ultra: Characterization and applications in enantioselective reactions. Tetrahedron Asymmetry 2009, 20, 2854-2860. [CrossRef]

33. Leśniarek, A.; Chojnacka, A.; Gładkowski, W. Application of Lecitase ${ }^{\circledR}$ Ultra-catalyzed hydrolysis to the kinetic resolution of (E)-4-phenylbut-3-en-2-yl esters. Catalysts 2018, 8, 423. [CrossRef]

34. Leśniarek, A.; Chojnacka, A.; Drozd, R.; Szymańska, M.; Gładkowski, W. Free and immobilized Lecitase ${ }^{\mathrm{TM}}$ Ultra as the biocatalyst in the kinetic resolution of (E)-4-arylbut-3-en-2-yl esters. Molecules 2020, 25, 1067. [CrossRef] [PubMed]

35. Garcia-Galan, C.; Berenguer-Murcia, Á.; Fernandez-Lafuente, R.; Rodrigues, R.C. Potential of different enzyme immobilization strategies to improve enzyme performance. Adv. Synth. Catal. 2011, 353, 2885-2904. [CrossRef]

36. Adlercreutz, P. Immobilisation and application of lipases in organic media. Chem. Soc. Rev. 2013, 42, 6406-6436. [CrossRef]

37. Di Cosimo, R.; Mc Auliffe, J.; Poulose, A.J.; Bohlmann, G. Industrial use of immobilized enzymes. Chem. Soc. Rev. 2013, 42, 6437-6474. [CrossRef]

38. Bilal, M.; Zhao, Y.; Noreen, S.; Shah, S.Z.H.; Bharagava, R.N.; Iqbal, H.M.N. Modifying bio-catalytic properties of enzymes for efficient biocatalysis: A review from immobilization strategies viewpoint. Biocatal. Biotransform. 2019, 37, 159-182. [CrossRef]

39. Alves, J.S.; Garcia-Galan, C.; Danelli, D.; Paludo, N.; Barbosa, O.; Rodrigues, R.C.; Fernandez-Lafuente, R. Use of Lecitase-Ultra immobilized on styrene-divinylbenzene beads as catalyst of esterification reactions: Effects of ultrasounds. Catal. Today 2015, 255, 27-32. [CrossRef]

40. Rueda, N.; Dos Santos, J.C.S.; Torres, R.; Ortiz, C.; Barbosa, O.; Fernandez-Lafuente, R. Improved performance of lipases immobilized on heterofunctional octyl-glyoxyl agarose beads. RSC Adv. 2015, 5, 11212-11222. [CrossRef] 
41. Zaak, H.; Fernandez-Lopez, L.; Otero, C.; Sassi, M.; Fernandez-Lafuente, R. Improved stability of immobilized lipases via modification with polyethylenimine and glutaraldehyde. Enzyme Microb. Technol. 2017, 106, 67-74. [CrossRef] [PubMed]

42. Arana-Peña, S.; Mendez-Sanchez, C.; Rios, N.S.; Ortiz, C.; Gonçalves, L.R.B.; Fernandez-Lafuente, R. New applications of glyoxyl-octyl agarose in lipases co-immobilization: Strategies to reuse the most stable lipase. Int. J. Biol. Macromol. 2019, 131, 989-997. [CrossRef] [PubMed]

43. Silva, F.B.d.; Morais Júnior, W.G.d.; Silva, C.V.d.; Vieira, A.T.; Batista, A.C.F.; Faria, A.M.d.; Assunção, R.M.N. Preparation and characterization of cellulose triacetate as support for Lecitase Ultra immobilization. Molecules 2017, 22, 1930. [CrossRef]

44. Baeza-Jiménez, R.; Noriega-Rodríguez, J.A.; García, H.S.; Otero, C. Structured phosphatidylcholine with elevated content of conjugated linoleic acid: Optimization by response surface methodology. Eur. J. Lipid Sci. Technol. 2012, 114, 1261-1267. [CrossRef]

45. Gan, L.J.; Wang, X.Y.; Yang, D.; Zhang, H.; Shin, J.A.; Hong, S.T.; Park, S.H.; Lee, K.T. Emulsifying properties of lecithin containing different fatty acids obtained by immobilized Lecitase Ultra-catalyzed reaction. J. Am. Oil Chem. Soc. 2014, 91, 579-590. [CrossRef]

46. Liu, N.; Wang, Y.; Zhao, Q.; Cui, C.; Fu, M.; Zhao, M. Immobilisation of Lecitase ${ }^{\circledR}$ Ultra for production of diacylglycerols by glycerolysis of soybean oil. Food Chem. 2012, 134, 301-307. [CrossRef]

47. Liu, N.; Fu, M.; Wang, Y.; Zhao, Q.; Sun, W.; Zhao, M. Immobilization of Lecitase ${ }^{\circledR}$ Ultra onto a novel polystyrene DA-201 resin: Characterization and biochemical properties. Appl. Biochem. Biotechnol. 2012, 168, 1108-1120. [CrossRef]

48. Baeza-Jiménez, R.; López-Martínez, L.X.; Otero, C.; Kim, I.H.; García, H.S. Enzyme-catalysed hydrolysis of phosphatidylcholine for the production of lysophosphatidylcholine. J. Chem. Technol. Biotechnol. 2013, 88, 1859-1863. [CrossRef]

49. Gonçalves, K.M.; Sutili, F.K.; Júnior, I.I.; Flores, M.C.; Soter De Mariz, E.; Miranda, L.; Leal, I.C.R.; Cordeiro, Y.; Luque, R.; De Souza, R.O.M.A. A comprehensive study on the activity and deactivation of immobilized Lecitase Ultra in esterifications of food waste streams to monoacylglycerols. ChemSusChem 2013, 6, 872-879. [CrossRef]

50. Yu, D.; Jiang, L.; Li, Z.; Shi, J.; Xue, J.; Kakuda, Y. Immobilization of phospholipase $\mathrm{A}_{1}$ and its application in soybean oil degumming. J. Am. Oil Chem. Soc. 2012, 89, 649-656. [CrossRef]

51. Sheelu, G.; Kavitha, G.; Fadnavis, N.W. Efficient immobilization of Lecitase in gelatin hydrogel and degumming of rice bran oil using a spinning basket reactor. J. Am. Oil Chem. Soc. 2008, 85, 739-748. [CrossRef]

52. Gonçalves, K.M.; Junior, I.I.; Papadimitriou, V.; Zoumpanioti, M.; Leal, I.C.R.; De Souza, R.O.M.A.; Cordeiro, Y.; Xenakis, A. Nanoencapsulated Lecitase Ultra and Thermomyces lanuginosus lipase, a comparative structural study. Langmuir 2016, 32, 6746-6756. [CrossRef] [PubMed]

53. Cabrera, Z.; Fernandez-Lorente, G.; Palomo, J.M.; Guisan, J.M.; Fernandez-Lafuente, R. Asymmetric hydrolysis of dimethyl 3-phenylglutarate catalyzed by Lecitase ${ }^{\circledR}$ Ultra. Effect of the immobilization protocol on its catalytic properties. Enzyme Microb. Technol. 2008, 43, 531-536. [CrossRef]

54. Fernandez-Lorente, G.; Filice, M.; Terreni, M.; Guisan, J.M.; Fernandez-Lafuente, R.; Palomo, J.M. Lecitase ${ }^{\circledR}$ Ultra as regioselective biocatalyst in the hydrolysis of fully protected carbohydrates. Strong modulation by using different immobilization protocols. J. Mol. Catal. B Enzym. 2008, 51, 110-117. [CrossRef]

55. Pinheiro, M.P.; Monteiro, R.R.C.; Silva, F.F.M.; Lemos, T.L.G.; Fernandez-Lafuente, R.; Gonçalves, L.R.B.; dos Santos, J.C.S. Modulation of Lecitase properties via immobilization on differently activated Immobead-350: Stabilization and inversion of enantiospecificity. Process. Biochem. 2019, 87, 128-137. [CrossRef]

56. Drozd, R.; Szymańska, M.; Rakoczy, R.; Junka, A.; Szymczyk, P.; Fijałkowski, K. Functionalized magnetic bacterial cellulose beads as carrier for Lecitase ${ }^{\circledR}$ Ultra immobilization. Appl. Biochem. Biotechnol. 2019, 187, 176-193. [CrossRef] [PubMed]

57. Brenna, E.; Caraccia, N.; Fuganti, C.; Fuganti, D.; Grasselli, P. Enantioselective synthesis of $\beta$-substituted butyric acid derivatives via orthoester Claisen rearrangement of enzymatically resolved allylic alcohols: Application to the synthesis of (R)-(-)-baclofen. Tetrahedron Asymmetry 1997, 8, 3801-3805. [CrossRef]

58. Brenna, E.; Fuganti, C.; Grasselli, P.; Serra, S. Enzyme-mediated synthesis of (S)- and (R)-Verapamil. Eur. J. Org. Chem. 2001, 1349-1357. [CrossRef] 
59. Gładkowski, W.; Skrobiszewski, A.; Mazur, M.; Gliszczyńska, A.; Czarnecka, M.; Pawlak, A.; Obmińska-Mrukowicz, B.; Maciejewska, G.; Białońska, A. Chiral $\delta$-iodo- $\gamma$-lactones derived from cuminaldehyde, 2,5-dimethylbenzaldehyde and piperonal: Chemoenzymatic synthesis and antiproliferative activity. Tetrahedron Asymmetry 2016, 27, 227-237. [CrossRef]

60. Gładkowski, W.; Włoch, A.; Pawlak, A.; Sysak, A.; Białońska, A.; Mazur, M.; Mituła, P.; Maciejewska, G.; Obmińska-Mrukowicz, B.; Kleszczyńska, H. Preparation of enantiomeric $\beta$-(2',5'-dimethylphenyl)bromolactones, their antiproliferative activity and effect on biological membranes. Molecules 2018, 23, 3035. [CrossRef]

61. Gumel, A.M.; Annuar, M.S.M. Thermomyces lanuginosus lipase-catalyzed synthesis of natural flavor esters in a continuous flow microreactor. 3 Biotech. 2016, 6, 24. [CrossRef] [PubMed]

62. Gładkowski, W.; Skrobiszewski, A.; Mazur, M.; Siepka, M.; Pawlak, A.; Obmińska-Mrukowicz, B.; Białońska, A.; Poradowski, D.; Drynda, A.; Urbaniak, M. Synthesis and anticancer activity of novel halolactones with $\beta$-aryl substituents from simple aromatic aldehydes. Tetrahedron 2013, 69, 10414-10423. [CrossRef]

63. Yamane, T. Importance of moisture content control for enzymatic reactions in organic solvents: A novel concept of "microaqueous". Biocatal. Biotransform. 1988, 2, 1-9. [CrossRef]

64. Colombo, G.; Ottolina, G.; Carrea, G. Modelling of enzyme properties in organic solvents. Mon. Chem. 2000, 131, 527-547. [CrossRef]

65. Kumar, A.; Dhar, K.; Kanwar, S.S.; Arora, P.K. Lipase catalysis in organic solvents: Advantages and applications. Biol. Proced. Online 2016, 18, 1-11. [CrossRef]

66. Kamal, Z.; Yedavalli, P.; Deshmukh, M.V.; Rao, N.M. Lipase in aqueous-polar organic solvents: Activity, structure, and stability. Protein Sci. 2013, 22, 904-915. [CrossRef]

67. Kazlauskas, R. Hydrolysis and formation of carboxylic acid and alcohol derivatives. In Organic Synthesis Using Biocatalysis; Goswami, A., Stewart, J.D., Eds.; Academic Press: Cambridge, MA, USA, 2016; pp. 127-148.

68. Laane, C.; Boeren, S.; Vos, K.; Veeger, C. Rules for optimization of biocatalysis in organic solvents. Biotechnol. Bioeng. 1987, 30, 81-87. [CrossRef]

69. Paravidino, M.; Hanefeld, U. Enzymatic acylation: Assessing the greenness of different acyl donors. Green Chem. 2011, 13, 2651-2657. [CrossRef]

70. Ghanem, A.; Aboul-Enein, H.Y. Application of lipases in kinetic resolution of racemates. Chirality 2005, 17, 1-15. [CrossRef]

71. Kawasaki, M.; Goto, M.; Kawabata, S.; Kometani, T. The effect of vinyl esters on the enantioselectivity of the lipase-catalysed transesterification of alcohols. Tetrahedron Asymmetry 2001, 12, 585-596. [CrossRef]

72. Chojnacka, A.; Obara, R.; Wawrzeńczyk, C. Kinetic resolution of racemic secondary aliphatic allylic alcohols in lipase-catalyzed transesterification. Tetrahedron Asymmetry 2007, 18, 101-107. [CrossRef]

73. Chênevert, R.; Pelchat, N.; Morin, P. Lipase-mediated enantioselective acylation of alcohols with functionalized vinyl esters: Acyl donor tolerance and applications. Tetrahedron Asymmetry 2009, 20, 1191-1196. [CrossRef]

74. Netto, C.G.C.M.; Andrade, L.H.; Toma, H.E. Enantioselective transesterification catalysis by Candida antarctica lipase immobilized on superparamagnetic nanoparticles. Tetrahedron Asymmetry 2009, 20, 2299-2304. [CrossRef]

75. Dong, F.; Li, L.; Lin, L.; He, D.; Chen, J.; Wei, W.; Wei, D. Transesterification synthesis of chloramphenicol esters with the lipase from Bacillus amyloliquefaciens. Molecules 2017, 22, 1523. [CrossRef]

76. Ghanem, A.; Schurig, V. Lipase-catalyzed irreversible transesterification of secondary alcohols using isopropenyl acetate. Monatshefte für Chemie 2003, 134, 1151-1157. [CrossRef]

77. Ghanem, A.; Schurig, V. Lipase-catalyzed irreversible transesterification of 1-(2-furyl)ethanol using isopropenyl acetate. Chirality 2001, 13, 118-123. [CrossRef]

78. Ghanem, A. The utility of cyclodextrins in lipase-catalyzed transesterification in organic solvents: Enhanced reaction rate and enantioselectivity. Org. Biomol. Chem. 2003, 1, 1282-1291. [CrossRef]

79. Brenna, E.; Fuganti, C.; Gatti, F.G.; Passoni, M.; Serra, S. Enantioselective synthesis of benzylic stereocentres via Claisen rearrangement of enantiomerically pure allylic alcohols: Preparation of $(R)-$ and (S)-3-methyl-2-phenylbutylamine. Tetrahedron Asymmetry 2003, 14, 2401-2406. [CrossRef] 
80. Brenna, E.; Dei Negri, C.; Fuganti, C.; Gatti, F.G.; Serra, S. Enantioselective synthesis of cis-7-methoxy-calamenene via Claisen rearrangement of an enzymatically resolved allyl alcohol. Tetrahedron Asymmetry 2004, 15, 335-340. [CrossRef]

81. Gładkowski, W.; Gliszczyńska, A.; Siepka, M.; Czarnecka, M.; Maciejewska, G. Kinetic resolution of $(E)-4$-(2',5'-dimethylphenyl)-but-3-en-2-ol and (E)-4-(benzo[ $d]\left[1^{\prime}, 3^{\prime}\right]$ dioxol-5'-yl)-but-3-en-2-ol through lipase-catalyzed transesterification. Tetrahedron Asymmetry 2015, 26, 702-709. [CrossRef]

82. Gładkowski, W.; Skrobiszewski, A.; Mazur, M.; Siepka, M.; Białońska, A. Convenient chemoenzymatic route to optically active $\beta$-aryl- $\delta$-iodo- $\gamma$-lactones and $\beta$-aryl- $\gamma$-iodo- $\delta$-lactones with the defined configurations of stereogenic centers. Eur. J. Org. Chem. 2015, 2015, 605-615. [CrossRef]

83. Mazur, M. Synthesis of halolactones with methoxyphenyl ring. Przem. Chem. 2011, 5, 918-922.

84. Boratyński, F.; Szczepańska, E.; Grudniewska, A.; Gniłka, R. Improving of hydrolases biosythesis by solid-state fermentation of Penicillium camemberti on rapeseed cake. Catalysts 2018, 8, 28. [CrossRef]

85. Skrobiszewski, A.; Gładkowski, W.; Maciejewska, G.; Wawrzeńczyk, C. Chemoenzymatic synthesis of trans- $\beta$-aryl- $\delta$-hydroxy- $\gamma$-lactones and enzymatic kinetic resolution of their racemic mixtures. Molecules 2016, 21, 1552. [CrossRef] [PubMed]

(C) 2020 by the authors. Licensee MDPI, Basel, Switzerland. This article is an open access article distributed under the terms and conditions of the Creative Commons Attribution (CC BY) license (http://creativecommons.org/licenses/by/4.0/). 